Etihad: Journal of Islamic Banking and Finance

Vol. 1, No. 2 Juli-Desember: 158-171

\title{
URGENSI KARAKTER DALAM ANALISIS PEMBIAYAAN MURABAHAH DI BANK SYARIAH INDONESIA
}

\section{Yulia Anggraini}

Institut Agama Islam Negeri Ponorogo; Indonesia

Email; anggraini@iainponorogo.ac.id

\begin{abstract}
The character of the customer is very important to analyze in the process of financing analysis. Character is an aspect of personal nature and concerns the depth of an individual's soul, so that character becomes difficult to identify. The purpose of this study was to determine whether Bank Syariah Indonesia KCP Nganjuk also conducted an in-depth character analysis. This field research uses a qualitative approach, with data collection techniques carried out using interviews and documentation. The data processing technique is done by data reduction, data presentation, and then conclusions. The results of this study are discrepancies in several points in the assessment using character analysis because at Bank Syariah Indonesia KCP Nganjuk implements 5C completely, although according to them, the character is important, the character can change along with financial conditions, economic conditions such as because of covid-19, dishonest customer character, manipulated business or work conditions, both stocks of goods and suppliers, purchases of goods are not by was proposed so that customer breaks his promise and does not fulfill his responsibility to repay the financing to the bank.
\end{abstract}

Keywords: Character; Financing Analysis; Islamic Bank; Murabahah

\begin{abstract}
Abstrak: Karakter nasabah adalah hal yang sangat penting untuk dianalisisis dalam proses analisis pembiayaan. Karakter merupakan aspek dengan sifat pribadi dan menyangkut kedalaman jiwa seorang individu, sehingga karakter menjadi sulit untuk dikenali. Tujuan penelitian ini adalah untuk mengetahui apakah Bank Syariah Indonesia KCP Nganjuk melakukan analisis karakter secara mendalam. Penelitian lapangan ini menggunakan pendekatan kualitatif, dengan teknik pengumpulan data wawancara dan dokumentasi. Teknik pengolahan data dilakukan dengan reduksi data, penyajian data, dan kemudian menarik kesimpulan. Hasil penelitian menunjukkan ketidaksesuaian dalam beberapa poin pada penilaian dengan menggunakan analisis karakter, karena di Bank Syariah Indonesia KCP Nganjuk menerapkan 5C secara lengkap, walaupun menurut mereka karakter adalah hal penting. Namun karakter bisa berubah seiring dengan kondisi keuangan, kondisi ekonomi seperti karena adanya covid-19, karakter nasabah yang tidak jujur, kondisi usaha, atau pekerjaan yang dimanipulasi baik stok barang dan supllier, pembelian barang tidak sesuai dengan yang diajukan, sehingga nasabah ingkar janji dan tidak memenuhi tanggung jawabnya untuk mengangsur pembiayaannya kepada pihak bank.
\end{abstract}

Keywords: Analisis Pembiayaan; Bank Syariah; Karakter; Murabahah; 
Etihad: Journal of Islamic Banking and Finance

Vol. 1, No. 2 Juli-Desember: 158-171

\section{PENDAHULUAN}

Kata "karasso" berasal dari bahasa Yunani yang mempunyai arti "karakter", atau biasa disebut format dasar, cetak biru, sidik, seperti dalam sidik jari (Afri Dewita, 2019) (Novita, 2017). Adapun penilaian-penilaian yang harus dilakukan oleh bank sebelum memberikan persetujuan terhadap adanya permintaan pembiayaan salah satunya adalah dengan melakukan penilaian karakter. Artinya bank mencermati secara sungguh-sungguh terkait dengan karakter dari calon nasabah (llyas, 2015). Menilai karakter adalah pekerjaan yang paling sulit dalam menganalisis pengajuan pembiayaan (Selvi Safitry \& Hendry, n.d.). Penilaian karakter calon nasabah pembiayaan sangat perlu dilaksanakan untuk menyimpulkan apakah calon nasabah pembiayaan tersebut jujur, mempunyai tujuan yang baik, dan tidak memiliki keinginan untuk tidak melakukan pembayaran dikemudian hari (Selvi Safitry \& Hendry, n.d.).

Bank Syariah Indonesia KCP Nganjuk adalah perbankan syariah yang melakukan proses bisnis untuk pembiayaan dan kemudian melakukan analisis untuk calon nasabah yang akan mengajukan pembiayaan tersebut apakah disetujui atau tidak. Ali Najamuddin selaku Branch Manager dari Bank Syariah Indonesia KCP Nganjuk mengatakan bahwa dalam melakukan pembiayaan, karakter seorang nasabah merupakan sesuatu yang bersifat sangat penting. Karakter itu bersifat dasar yang sangat sulit untuk diubah, sehingga karakter merupakan salah satu yang menjadi prioritas utama Bank Syariah Indonesia KCP Nganjuk dalam melakukan analisis pembiayaan kepada calon nasabah (Najamuddin, 2021). Dalam menjalankan proses pembiayaan tersebut, maka masih muncul berbagai masalah yang di dalamnnya dan menimbulkan pembiayaan bermasalah. Setelah diteliti, masalah ini terjadi antara lain karena karakter nasabah yang tidak jujur, kondisi usaha atau pekerjaan yang dimanipulasi baik stok barang dan supllier, pembelian barang tidak sesuai dengan yang diajukan sehingga akhirnya nasabah ingkar janji dan tidak memenuhi tanggung jawabnya untuk mengangsur kepada pihak bank (Geged, 2021).

Kasmir mengatakan bahwa sebelum suatu fasilitas kredit diberikan, maka bank harus merasa yakin bahwa kredit yang diberikan benar-benar akan kembali. Keyakinan tersebut diperoleh dari hasil penilaian pembiayaan sebelum pembiayaan tersebut disalurkan. Dalam melakukan penilaian kriteria-kriteria serta aspek penilaiannya tetap sama. Begitu pula dengan ukuran-ukuran yang ditetapkan sudah menjadi standar penilaian setiap bank (Geged, 2021).

Analisis penilaian pembiayaan merupakan suatu proses analisis yang dilakukan oleh bank syariah untuk menilai suatu permohonan pembiayaan yang telah dilakukan oleh calon nasabah. Prinsip dasar tersebut adalah Character, Capacity, Capital, Collateral, dan Condition of Economy. Karakter yang merupakan sifat dasar dari calon nasabah yang terdiri dari orangorang yang akan diberikan pembiayaan benar-benar dapat dipercaya. Hal ini tercermin dari latar belakang nasabah di lingkungan kerjanya dan juga latar belakang di lingkungan pribadinya, seperti gaya hidup, keadaan keluarga, hobi, dan social standingnya. Ini semua merupakan ukuran kemauan membayar. Karakter merupakan penilaian yang diutamakan oleh bank (Kasmir, 2016). Berdasarkan penuturan yang disampaikan oleh Branch Manager Bank Syariah Indonesia KCP Nganjuk analisis karakter dilakukan dengan adanya pengecekan SID 
Etihad: Journal of Islamic Banking and Finance

Vol. 1, No. 2 Juli-Desember: 158-171

(Sistem Informasi Debitur) dan DHN (Daftar Hitam Nasional) terlebih dahulu sebelum pengecekan secara langsung dengan survei ke lokasi usaha, lokasi jaminan, mengecek jumlah stok barang dagangan, dan tentunya lingkungan hidup dari calon nasabah (Najamuddin, 2021).

Penelitian Dian Hurriyah yang berjudul "Analisis Penilaian Karakter dalam Penyaluran Pembiayaan Murabahah pada KSPPS BMT Al-Fatayya Payakumbuh". Hasil penelitian menjelasakan, BMT Al-Fatayya mengutamakan analisis penilaian karakter karena nasabah BMT Al-Fatayya pada umumnya pedagang dan pengusaha kecil yang berada di Pasar Ibuh Payakumbuh yang tidak jauh dari BMT tersebut, sehingga memudahkan bagi pihak BMT AlFataya untuk mengenal nasabah (Hurriyah, 2018). Namun menurut Ali Najamuddin mengatakan bahwa tidak hanya karakter yang dipentingkan, karena sebenarnya analisis 5C saling terkait satu sama lain, ada juga nasabah yang sangat kooperatif dalam melakukan pembayaran namun kondisi usaha, seperti ditipu oleh rekan bisnis, ataupun dengan adanya wabah covid-19 yang sangat berpengaruh terhadap pembiayaan yang eksisting maupun yang akan dianalisis (Najamuddin, 2021).

Pembiayaan murabahah mendominasi jumlah pembiayaan pada Bank Syariah Indonesia. Murabahah dengan akad jual beli dengan tambahan margin yang digunakan untuk pembelian barang baik digunakan untuk usaha maupun untuk konsumsi. Pembiayaan murabahah berjumlah $85 \%$ dari total pembiayaan di Bank Syariah Indonesia yang tentunya sebagai penyumbang pembiayaan bermasalah terbesar (Geged, 2021).

Pembiayaan bermasalah merupakan pembiayaan yang telah disalurkan oleh bank, dan nasabah tidak dapat melakukan pembayaran atau mengangsur cicilan sesuai dengan perjanjian akad pembiayaan yang telah ditandatangani oleh bank, notaris dan nasabah. Pembiayaan bermasalah akan berakibat pada kerugian bank, yaitu kerugian karena tidak diterimanya kembali dana yang telah disalurkan (Ismail, 2016). Dampak dari penilaian karakter yang kurang tepat kepada calon nasabah di Bank Syariah Indonesia KCP Nganjuk salah satunya adalah pembiayaan macet atau pembiayaan bermasalah yang dibuktikan dengan tingginya tingkat NPF (Non Performing Loan) pembiayaan murabahah pada Desember 2020 dengan sebesar Rp 653.256.800 dibandingkan dengan November 2021 sebesar Rp 897.652.258.

Dari latar belakang dan permasalahan yang dibahas di atas, maka penulis tertarik untuk meneliti Urgensi Karakter dalam Analisis Pembiayaan Murabahah di Bank Syariah Indonesia.

\section{TINJAUAN LITERATUR}

Pembiayaan merupakan pendanaan yang dikeluarkan untuk mendukung investasi yang telah direncanakan, baik dilakukan sendiri maupun dijalankan orang lain. Dalam arti sempit, pembiayaan dipakai untuk mendefinisikan pendanaan yang dilakukan oleh lembaga pembiayaan, seperti bank syariah kepada nasabah (Andrianto \& Firmansyah, 2019). Dalam melakukan pendanaan analisis pembiayaan merupakan salah satu faktor yang sangat penting bagi bank syariah dalam mengambil keputusan untuk menyetujui atau menolak permohonan 
Etihad: Journal of Islamic Banking and Finance

Vol. 1, No. 2 Juli-Desember: 158-171

pembiayaan. Analisis pembiayaan dapat digunakan sebagai acuan bagi bank syariah untuk meyakini kelayakan atas permohonan pembiayaan nasabah.

\section{Analisis Watak (Character)}

Pengertian Karakter menurut Pusat Bahasa Depdiknas adalah "bawaan, hati, jiwa, kepribadian, budi pekerti, perilaku, personalitas, sifat, tabiat, temperamen, atau watak". Karakter mengacu kepada beberapa serangkaian sikap (attitude), perilaku (behavior), motivasi (motivation), dan keterampilan (skill) (Afri Dewita, 2019).

Sedangkan menurut Andrianto, karakter adalah keadaan watak atau sifat dari customer, baik dalam kehidupan pribadi maupun dalam lingkungan usaha. Kegunaan dari penilaian terhadap karakter adalah untuk mengetahui sejauh mana iktikad atau kemauan customer untuk memenuhi kewajibannya (willingness to pay) sesuai dengan perjanjian yang telah ditetapkan. Penilaian karakter merupakan faktor yang dominan, karena jika nasabah mampu untuk menyelesaikan utangnya tetapi tidak mempunyai iktikad baik, maka akan membawa berbagai kesulitan bagi bank di kemudian hari (Andrianto \& Firmansyah, 2019). Pemberian pembiayaan harus atas dasar kepercayaan, sedangkan yang mendasari suatu kepercayaan yaitu adanya keyakinan dari pihak bank, bahwa peminjam memiliki moral, watak, dan sifat-sifat pribadi yang positif dan kooperatif. Di samping itu mempunyai rasa tanggung jawab, baik dalam kehidupan pribadi sebagai manusia, kehidupannya sebagai anggota masyarakat, maupun dalam menjalankan kegiatan usahanya.

Sarana yang digunakan dalam menilai karakter nasabah Bank ingin mengetahui bahwa calon debitur mempunyai karakter yang baik, jujur, dan mempunyai komitmen terhadap pelunasan kredit yang akan diterima bank. Cara yang perlu dilakukan oleh bank dalam mengetahui karakter calon debitur adalah melakukan penelitian yang mendalam tentang calon debitur.

Cara yang perlu dilakukan oleh bank dalam analisis karakter dapat dilakukan dengan (Ismail, 2016) :

1. SLIK OJK atau sebelumnya disebut dengan BI Checking

Sistem Layanan Informasi Keuangan atau SLIK sendiri merupakan sistem informasi yang pengelolaannya di bawah tanggung jawab OJK yang bertujuan untuk melaksanakan tugas pengawasan dan pelayanan informasi keuangan yang salah satunya berupa penyediaan informasi debitur (iDeb).

SLIK memperluas cakupan iDeb yaitu melingkupi lembaga keuangan bank dan lembaga pembiayaan (finance) dan juga ke lembaga keuangan non-bank yang mempunyai akses data debitur serta kewajiban melaporkan data debitur ke Sistem Informasi Debitur (SID). Selain itu, SLIK juga dipakai untuk melaporkan, fasilitas penyediaan dana, data agunan, dan data terkait lainnya dari berbagai jenis lembaga keuangan, masyarakat, Lembaga Pengelolaan Informasi Perkreditan (LPIP) dan pihak lainnya (Sistem Layanan Informasi Keuangan (SLIK), 2021). 
Etihad: Journal of Islamic Banking and Finance

Vol. 1, No. 2 Juli-Desember: 158-171

2. Informasi dari pihak lain

Dalam hal calon nasabah masih belum memiliki pinjaman di bank lain, maka cara yang efektif ditempuh yaitu dengan meneliti calon nasabah melalui pihak-pihak lain yang mengenal dengan baik calon nasabah. Misalnya mencari informasi tentang karakter calon nasabah melalui tetangga, teman kerja, atasan langsung, dan rekan usahanya. Informasi dari pihak lain akan lebih meyakinkan bank untuk mengetahui karakter calon nasabah. Karakter merupakan faktor yang sangat penting dalam evaluasi calon nasabah (Budiantoro, 2014).

3. Wawancara

Wawancara secara langsung kepada nasabah dan pihak lain yang disebut oleh nasabah sebagai pihak yang dikenal dan tidak serumah. Bank juga perlu mendapat informasi dari perusahaan di mana nasabah bekerja. Hal ini sering dilakukan oleh bank dengan wawancara by phone. Wawancara ini diperlukan antara lain untuk (Ismail, 2016);

a. Mengetahui berbagai hal tentang nasabah

b. Melakukan cross check terhadap isian dalam formulir permohonan kredit dengan informasi lisan

c. Mempelajari karakter calon nasabah

4. Melihat dari status dan riwayat hidup, dengan melihat apakah calon nasabah memiliki istri lebih dari satu, sudah menikah atau belum menikah, janda atau duda, latar belakang pekerjaan.

5. Checking In Club, menanyakan karakter calon nasabah kepada perkumpulan yang dinaungi seperti jamaah masjid, komunitas sosial, kelompok pergerejaan, dan lain-lain.

6. Pengecekan DHN (Daftar Hitam Nasabah), melakukan cross check dengan bank pemberi pembiayaan bagaimanakah track record calon nasabah. Daftar hitam nasional atau yang biasa disebut blacklist adalah salah satu upaya yang dilakukan oleh Bank Indonesia untuk mencegah peredaran cek dan atau bilyet giro kosong. Sesuai dengan Peraturan Bank Indonesia Nomor 8/29/PBI/2006 tentang Daftar Hitam Nasional Penarik Cek dan atau Bilyet Kosong bagi pihak yang memberikan cek kosong sesuai dengan peraturan tersebut, maka akan dikenakan sanksi yaitu namanya dimasukkan ke dalam Daftar Hitam Nasional yang ditentukan oleh Bank Indonesia (OJK, 2021a).

7. Lakukan pengecekan dengan Supplier, bagaimanakah ketepatan pembayaran calon nasabah, apakah tepat waktu atau sering terlambat.

8. Memperlajari karakter masyarakat setempat, karena adat di setiap daerah sangat berbeda, apakah calon nasabah masuk dalam daftar masyarakat yang disegani di daerah itu? Kenapa disegani? Apakah karena mempunyai nama baik yang besar atau sebaliknya mempunyai reputasi buruk (Andrianto \& Firmansyah, 2019).

Menurut Undang-Undang Perbankan nomor 10 tahun 1998 pengertian pembiayaan adalah penyediaan uang atau tagihan yang dapat dipersamakan dengan itu yang erdasarkan persetujuan atau kesepakatan antara bank dengan pihak lain yang mewajibkan pihak yang 
Etihad: Journal of Islamic Banking and Finance

Vol. 1, No. 2 Juli-Desember: 158-171

dibiayai untuk mengembalikan uang atau tagihan setelah jangka waktu tertentu dengan imbalan atau bagi hasil (Bprartorejobatu, 2021).

Analisis pembiayaan merupakan suatu proses analisis yang dilakukan oleh bank syariah untuk menilai suatu permohonan pembiayaan yang telah diajukan oleh calon nasabah, sehingga dengan melakukan analisis permohonan pembiayaan, maka bank syariah dapat memperoleh keyakinan bahwa proyek yang dibiayai layak (feasible) (Ismail, 2016).

Pada prinsipnya, istilah pembiayaan pada perbankan syariah memiliki konsep serupa dengan istilah kredit pada perbankan konvensional. Bank syariah dalam menyalurkan pembiayaan juga membutuhkan tahap-tahap analisis yang matang terhadap calon nasabah. Dengan adanya analisis yang baik akan menghasilkan keputusan yang tepat, sehingga analisis pembiayaan merupakan salah satu faktor yang sangat penting dalam keputusan pembiayaan kepada calon nasabah (Kasmir, 2013).

Berikutnya adalah penjelasan tentang prinsip 5C:

1. Character.

Suatu keyakinan bahwa sifat atau watak dari nasabah yang akan diberikan pembiayaan benar-benar dapat dipercaya. Hal ini tercermin dari latar belakang nasabah yang bersifat latar belakang pekerjaan maupun yang bersifat pribadi seperti: cara hidup atau gaya hidup yang dianutnya, keadaan keluarga, hoby dan social standingnya (Kasmir, 2016).

Bank ingin meyakini wilingness to repay dari calon nasabah, yaitu keyakinan bank terhadap kemauan calon nasabah yang memenuhi kewajibannya sesuai dengan jangka waktu yang diperjanjikan. Bank ingin mengetahui bahwa calon nasabah mempunyai karakter yang baik, jujur dan mempunyai komitmen terhadap pembayaran kembali pembiayaannya (Ismail, 2016).

2. Capacity

Untuk melihat nasabah dalam kemampuannya dalam bidang bisnis yang dihubungkan dengan pendidikannya, kemampuan bisnis juga diukur dengan kemampuannya dalam memahami tentang ketentuan-ketentuan pemerintah.

Beberapa cara yang dapat ditempuh dalam mengetahui kemampuan keuangan calon nasabah antara lain (Ismail, 2016):

a. Melihat laporan keuangan. Dalam laporan keuangan calon nasabah, maka dapat diketahui sumber dananya, dengan melihat laporan arus kas. Di dalam laporan arus kas secara keseluruhan dapat diketahui kondisi keuangan secara tunai dari calon nasabah, dengan membandingkan antara sumber dana yang diperoleh dan penggunaan dana.

b. Memeriksa slip gaji dan rekening tabungan. Cara lain yang dapat ditempuh oleh bank syariah, bila calon nasabah pegawai, maka bank dapat meminta fotokopi slip gaji tiga bulan terakhir dan didukung oleh rekening tabungan sekurang-kurangnya untuk tiga bulan terakhir. Dari data tersebut, maka dapat dianalisis tentang sumber dana dan penggunaan dana calon nasabah. 
Etihad: Journal of Islamic Banking and Finance

Vol. 1, No. 2 Juli-Desember: 158-171

c. Survei ke lokasi usaha calon nasabah. Survei ini diperlukan untuk mengetahui usaha calon nasabah dengan melakukan pengamatan secara langsung.

3. Capital

Untuk melihat apakah modal efektif, dilihat dari laporan keuangannya (neraca dan laba rugi). Dengan melakukan pengukuran seperti dari segi likuiditas, solvabilitas, rentabilitas, dan ukuran lainnya (Pengertian, Fungsi Dan Jenis Analisis Rasio Keuangan, 2021). Capital juga harus dilihat dari mana saja sumber modal yang ada sekarang ini. Modal sendiri juga menjadi bahan pertimbangan bank sebagai bukti kesungguhan dan tanggung jawab mudharib dalam menjalankan usahanya, karena ikut menanggung risiko terhadap gagalnya usaha. Dalam praktiknya, kemampuan capital ini dimanifestasikan dalam bentuk kewajiban untuk menyediakan self-financial, yang sebaliknya jumlahnya lebih besar dari pembiayaan yang diminta kepada bank. Bentuk dari self financial ini tidak selalu harus berupa uang tunai, bisa juga dalam bentuk barang modal seperti tanah, bangunan dan mesin-mesin (Andrianto \& Firmansyah, 2019).

4. Collateral

Merupakan jaminan yang diberikan calon nasabah baik secara fisik maupun non fisik. Jaminan hendaknya melebihi jumlah kredit yang diberikan. Jaminan juga harus diteliti keabsahannya, sehingga jika terjadi suatu masalah dikemudian hari, maka jaminan yang dititipkan dapat dipergunakan secepat mungkin (Kasmir, 2016). Secara perinci pertimbangan atas collateral dikenal dengan MAST (Ismail, 2016) dengan penjelasan sebagai berikut:

a. Marketability. Agunan yang diterima oleh bank harusnya agunan yang mudah diperjualbelikan dengan harga yang menarik dan meningkat dari waktu ke waktu. Sehingga pihak bank lebih mudah ketika melakukan penjualan.

b. Ascertainability. Agunan yang diterima memiliki standar harga yang lebih pasti, sehingga tidak menyulitkan bank ketika melakukan analisis terhadap agunan yang diberikan.

c. Stability of value. Agunan yang diserahkan kepada bank mempunyai harga yang stabil, sehingga ketika agunan dijual maka hasil penjualan bisa meng-cover kewajiban debitur. Hal ini bertujuan untuk meminimalisasi permasalahan nasabah dalam melakukan pengembalian pembiayaan.

d. Transferability. Agunan yang diserahkan bank mudah dipindah tangankan dan mudah dipindahkan dari stau tempat ke tempat lainnya.

\section{Condition of Economy}

Dalam menilai kredit, hendaknya juga dinilai konsisi ekonomi dan politik sekarang dan di masa yang akan datang sesuai dengan sektor masing-masing, serta prospek usaha hendaknya memimiliki prospek-prospek usaha yang baik, sehingga kemungkinan kredittersebut bermasalah sangat kecil (Kasmir, 2016). Bank perlu mempertimbangkan sektor usaha calon debitur dikaitkan dengan kondisi ekonomi. Apakah kondisi ekonomi tersebut dapat berpengaruh pada usaha calon debitur di masa yang mendatang. Beberapa analisis yang perlu dilakukan adalah kebijakan pemerintah. Apabila kebijakan pemerintah 
Etihad: Journal of Islamic Banking and Finance

Vol. 1, No. 2 Juli-Desember: 158-171

sering berubah, maka hal ini juga akan sulit bagi bank untuk melakukan analisis condition of economy (Kasmir, 2016).

Tujuan analisis pembiayaan merupakan langkah paling penting untuk realisasi pembiayaan. Proses yang dilakukan oleh pelaksana (pejabat) pembiayaan ini untuk:

1. Menilai kelayakan usaha calon peminjam,

2. Menekan risiko akibat tidak terbayarnya pembiayaan

3. Menghitung kebutuhan pembiayaan yang layak (Andrianto \& Firmansyah, 2019).

Adapun tujuan utama analisis permohonan pembiayaan adalah untuk memperoleh keyakinan apakah nasabah punya kemauan dan kemampuan memenuhi kewajiban secara tertib, baik pembayaran pokok pinjaman maupun nisbah bagi hasil sesuai dengan kesepakatan dengan bank. Dalam pemberian pembiayaan kepada customer atau nasabah, maka didapati risiko yang dihadapi, yaitu tidak kembalinya uang yang dipinjamkan kepada customer. Oleh karena itu, keadaan dan perkembangan customer harus diikuti secara terus-menerus mulai saat pembiayaan diberikan sampai pembiayaan lunas (Saiful, 2021). Dalam menganalisis pembiayaan, pertama-tama yang harus diperhatikan adalah kemauan dan kemampuan customer untuk memenuhi kewajibannya. Faktor lain yang harus diperhatikan adalah perekonomian atau aktivitas pada umumnya (ekonomi makro dan AMDAL). Mengingat risiko tidak kembalinya pembiayaan selalu ada, maka setiap pembiayaan harus disertai jaminan yang cukup, sesuai dengan yang ada. Sehingga bank tidak mengalami kerugian dalam pembiayaan yang telah disalurkan kepada nasabah. Hal ini termasuk cara untuk menghindari atau meminimalisasi terjadinya resiko pembiayaan (Aris, 2021).

\section{METODE PENELITIAN}

Dalam penelitian ini, penulis menggunakan pendekatan penelitian kualitatif. Penelitian kualitatif yaitu metode penelitian yang berlandaskan pada filsafat post-positivisme yang digunakan untuk meneliti kondisi objek yang alamiah. Di mana peneliti sebagai objek yang alamiah dam peneliti sebagai instrumen kunci serta menghasilkan data deskriptif berupa katakata yang tertulis atau lisan dari orang-orang atau perilaku yang dialami (Sugiyono, 2017). Dalam hal ini peneliti secara langsung melakukan wawancara dengan pihak Bank Syariah Indonesia KCP Nganjuk.

Teknik atau metode pengumpulan data dalam penelitian ini tujuan utamanya adalah mendapatkan data dan instrumen penelitian yang mengumpulkan fakta-fakta sosial yang dapat dilakukan dengan menggunakan berbagai instrumen penelitian (Sugiyono, 2017) sebagaimana berikut;

1. Wawancara. Metode wawancara digunakan untuk memperoleh keterangan dengan cara tanya jawab sambil bertatap muka antara pewawancara dengan responden atau orang yang diwawancarai. Wawancara akan dilakukan kepada pihak bank yang berkaitan dengan permasalahan yang sedang diteliti dan dilakukan setelah peneliti menulis atau mencatat. Wawancara digunakan untuk memperoleh data terkait dengan profil perusahaan 
Etihad: Journal of Islamic Banking and Finance

Vol. 1, No. 2 Juli-Desember: 158-171

penelitian, Visi Misi perusahaan, Identitas umum perusahaan, produk operasional perusahaan, dan analisis dalam pemberian pembiayaan.

2. Dokumentasi. Selain teknik wawancara, peneliti juga memakai teknik dokumentasi dalam mengumpulkan data penelitian. Studi dokumen merupakan pelengkap dari penggunaan metode observasi dan wawancara dalam penelitian kualitatif. Teknik pengumpulan data melalui dokumentasi merupakan pelengkap dalam penelitian kualitatif. Dokumentasi dalam penelitian ini berupa analisis pembiayaan, data tentang sejarah lembaga itu sendiri dan data-data yang berhubungan dengan pokok penelitian.

Peneliti menggunakan teknik triangulasi yang merupakan aplikasi studi yang menggunakan multimetode untuk menelaah fenomena yang sama (Danim, 2002). Peneliti menganalisis data penelitian menggunakan metode induktif. Analisis data yang dilakukan bersifat induktif berdasarkan fakta-fakta yang ditemukan di lapangan dan kemudian dikonstruksikan menjadi hipotesis atau teori (Sugiyono, 2017). Data-data yang diperoleh dalam penelitian berupa pembiayaan, analisis karakter dalam pengajuan pembiayaan, dan analisis perilaku pembiayaan. Peneliti mengawali penelitian ini dengan memaparkan faktafakta, kemudian dan mengakhirinya dengan teori pembiayaan serta analisis karakter pembiayaan.

\section{HASIL DAN PEMBAHASAN}

Prosedur pemberian pembiayaan murabahah kepada calon nasabah di Bank Syariah Indonesia KCP Nganjuk yaitu dengan menerapkan mekanisme yang dilakukan dalam pengajuan pembiayaan seperti pada umumnya. Pertama calon nasabah harus menjadi nasabah tabungan terlebih dahulu di Bank Syariah Indonesia KCP Nganjuk, baru kemudian bisa mengajukan permohonan pembiayaan. Selanjutnya membuat daftar rencana pembiayaan, yang berisi barang apa saja yang akan dibeli oleh calon nasabah. Kemudian dilakukan pengumpulan data yang digunakan sebagai syarat pengajuan pembiayaan murabahah. Selanjutnya dilakukan analisis prinsip 5C. Jika analisis 5C sudah terlaksana, maka konfirmasi dengan nasabah apakah pembiayaan tersebut disetujui atau tidak. Jika disetujui maka selajutnya dilakukan akad antara kedua belah pihak. Kemudian melakukan pencairan dana. Berikut adalah gambaran prosedur pembiayaan yang dilakukan (Najamuddin, 2021):

Permohonan

Pembiayaan oleh nasabah
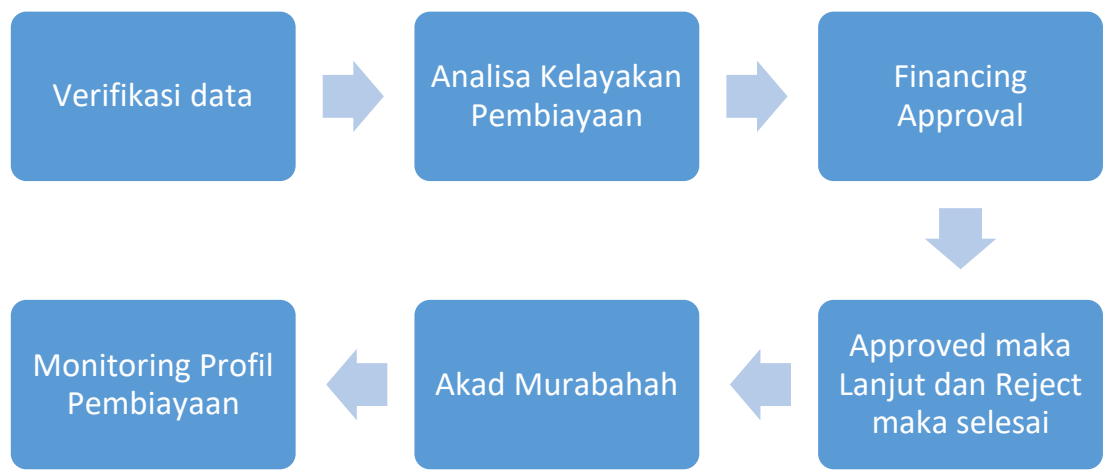

Financing

Approval

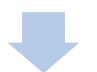

Approved maka

Lanjut dan Reject maka selesai

Gambar 1: Proses Pembiayaan Murabahah di Bank Syariah Indonesia Nganjuk 
Etihad: Journal of Islamic Banking and Finance

Vol. 1, No. 2 Juli-Desember: 158-171

Dalam menilai karakter calon nasabah, pihak bank ingin mengetahui bahwa calon debitur mempunyai karakter yang baik, jujur, dan tentunya mempunyai komitmen menangsur pinjaman sampai pelunasan. Cara yang perlu dilakukan oleh bank dalam mengetahui karakter calon nasabah pembiayaan murabahah adalah dengan melakukan penelitian yang mendalam tentang karakter dari calon nasabah.

1. SLIK OK

Sistem Layanan Informasi Keuangan atau SLIK sendiri merupakan sistem informasi yang pengelolaannya di bawah tanggung jawab OJK yang bertujuan melaksanakan tugas pengawasan dan pelayanan informasi keuangan, yang salah satunya berupa penyediaan informasi debitur (iDeb) (OJK, 2021b).

Informasi dari Ali Najamuddin tentang penggunaan SLIK OJK : "Ini adalah tahap yang harus dilakukan, jadi proses awal itu ya pengecekan SID dengan SLIK OJK ini, sehingga akan dapat diketahui bagaimana Riwayat pembayaran dari calon nasabah, apakah lancar atau tidak, memiliki pinjaman apa saja dan berapa jumlahnya, sehingga bis akita hitung kemampuan bayar dari calon nasabah tersebut sehingga bisa diputuskan apakah pemberian pembiayaan bisa dilakukan ataupun tidak, dan berapa maksimal pinjaman yang bisa diberikan,"(Najamuddin, 2021).

Geged sebagai Unit Head juga mengatakan bahwa : "Jadi proses awal itu ya ini, jadi banyak calon nasabah gagal pengajuan karena setelah dicek pembayaran tidak lancar atau macet, sehingga tentunya kita tidak dapat meberikan tambahan pinjaman untuk mereka"(Aris, 2021).

Informasi dari Ali Najamuddin dan Geged tentang penggunaan SLIK OJK menunjukkan bahwa Bank Syariah Indonesia KCP Nganjuk sudah menggunakan SLIK OJK. Hal demikian guna melihat dan menganalisis data calon nasabah dalam pembiayaan yang dilakukan oleh calon nasabah tersebut melalui Lembaga keuangan yang sudah terdaftar di OJK serta menganalisis pembayaran angsuran oleh calon nasabah, apakah lancar atau tidak, sehingga Bank Syariah Indonesia KCP Nganjuk sudah sesuai dengan teori yaitu dengan menggunakan SLIK OJK untuk melihat karakter dari calon nasabah pembiayaan murabahah.

2. Informasi dari pihak lain

Ketika hal calon nasabah masih belum memiliki pinjaman di bank lain, maka cara yang efektif ditempuh yaitu dengan meneliti calon nasabah melalui pihak-pihak lain yang mengenal baik calon nasabah. Misalnya mencari informasi tentang karakter calon nasabah melalui tetangga, teman kerja, atasan langsung, dan rekan usahanya. Informasi dari pihak lain lebih meyakinkan bank untuk mengetahui karakter calon nasabah. Karakter merupakan faktor yang sangat penting dalam evaluasi calon nasabah. Namun informasi ini juga sangat dibutuhkan walaupun sudah menganalisis dengan SLIK OJK, di mana informasi ini sangat penting untuk mengetahui bagaimana karakter seseorang.

Aris sebagai Account Officer mengatakan : "hal yang penting adalah mencari informasi dari pihak lain ini, dimana kadang karakter seseorang terbuka disini, tapi ya pintar-pintarnya mencari informan di lapangan, karena saat salah informan maka akan membuat salah Analisis."(Aris, 2021). 
Etihad: Journal of Islamic Banking and Finance

Vol. 1, No. 2 Juli-Desember: 158-171

Saiful dengan posisi Account Officer menanggapi: "kadang informasi dari pihak lain ini yang membuat kita lebih percaya selain dari hasil Slik, jadi info ini penting sekali ya, karena di lapangan itu orang berbeda-beda, kadang walaupun terlihat usaha dan agunan bagus, tapi kemudian karakternya jelek ya gak bayar."(Saiful, 2021).

Bank Syariah Indonesia KCP Nganjuk sudah melakukan analisis karakter dengan mencari informan yang berkaitan dengan calon nasabah yang akan dibiayai. Harapannya ke depan ialah nasabah dapat membayar angsuran sesuai dengan kesepakatan.

3. Mempelajari karakter calon nasabah

Mempelajari karakter ketika melakukan wawancara dengan calon nasabah. Dalam menilai karakter tentunya perlu memperhatikan nilai-nilai yang terdapat dalam diri calon nasabah tersebut.

Mempelajari karakter calon nasabah yaitu ketika melakukan wawancara dengan memperhatikan karakter calon nasabah. Ali Najamuddin menanggapi hal ini: "Kalau memepelajari pasti ya, cuma untuk mengetahui itu agak susah ya, karena kadang karena keadaan maka karakter akan berubah sih, sehingga sebisa mungkin dengan data yang ada ya kita mempelajari karakter calon nasabah yang akan kita beri pinjaman, dan mempelajari calon nasabah ini kita harus cermat dan detail, dengan mengajak ngobrol secara mendalam dan bisa berbekal dari data SLIK OJK dan informasi dari banyak pihak."(Najamuddin, 2021).

Untuk mempelajari karakter calon nasabah, Bank Syariah Indonesia KCP Nganjuk sudah melakukan dengan melakukan pendekatan personal secara mendalam, sehingga karakter akan terbaca dengan keakraban dari obrolan ringan namun cermat dan detail, walaupun menurut Ali Najamuddin hal ini tidak selalu terjadi, banyak nasabah yang karakternya bagus tapi belum tentu lancar dalam pembayaran angsuran dikarenakan keadaan dari keuangan dari calon nasabah tersebut.

4. Melihat dari status dan riwayat hidup

Melihat dari status dan riwayat hidup dapat dilihat apakah calon nasabah memiliki istri lebih dari satu, sudah menikah atau belum menikah, janda atau duda, latar belakang pekerjaan. Sesuai teori dari Ismail ini, Ali Najamuddin menanggapi :"Kalo dari status dan riwayat hidup kita paling tau ya dari data dan informasi sekitar apabila sebelumnya kita tidak kenal, namun apabila nasabah itu didapat dari hasil referral maka akan lebih mudah untuk membaca riwayat hidupnya."(Najamuddin, 2021).

Melihat status dan riwayat hidup misalnya melihat apakah calon nasabah memiliki istri lebih dari satu, sudah menikah atau belum menikah, janda atau duda, latar belakang pekerjaan. Sesuai teori dari Ismail maka Bank Syariah Indonesia KCP Nganjuk sudah melakukan analisis dengan melihat status dan riwayat hidup dari identitas dan informasi dari banyak pihak, namun tetap menjadi pertimbangan yang mendalam atas analisis riwayat hidup serta status dari calon nasabah yang akan dibiayai oleh Bank Syariah Indonesia KCP Nganjuk.

\section{Checking In Club}

Checking In Club dengan karakter calon nasabah kepada perkumpulan yang dinaungi seperti jamaah masjid, komunitas sosial, kelompok pergerejaan, dan lain-lain. Menurut Geged: "Perkumpulan ini biasanya seiring waktu dan keakraban akan dapat dilihat dan 
Etihad: Journal of Islamic Banking and Finance

Vol. 1, No. 2 Juli-Desember: 158-171

dicek, namun kalo dari Bank Syariah Indonesia KCP Nganjuk sendiri biasanya tidak sematasemata, tetapi bisa secara tidak langsung waktu mampir atau makan di warung dan ngobrol dengan orang biasanya kita bisa sekalian menggali informasi di sini."(Geged, 2021).

Sedangkan menurut Ali Najamuddin "Kalau mengecek biasanya kita bisanya saat calon nasabah juga merupakan karyawan dan kita biasanya bertanya di lingkungan kerjanya, contohnya bendahara atau pimpinan, namun hal ini tidak selalu kita lakukan karena untuk pembiayaan murabahah kebanyakan dari wirausaha dan bukan karyawan"(Najamuddin, 2021).

Checking In Club yaitu menanyakan karakter calon nasabah pada perkumpulan yang dinaunginya, seperti jamaah masjid, komunitas sosial, kelompok pergerejaan, dan lain-lain. Pihak Bank Syariah Indonesia KCP Nganjuk juga tengah melakukan cek namun bukan di awal saja, tetapi dilakukan seiring berjalannya waktu, karena dikejar dengan pencairan. Upaya ini dilakukan guna mengecek secara lebih karena mayoritas pembiayaan murabahah berasal dari wirausahawan. Adapun pengecekan biasanya dilakukan di tempat kerja, sehingga untuk hal ini tidak selalu dilakukan.

6. Pengecekan DHN (Daftar Hitam Nasabah)

Melakukan cross check dengan bank pemberi pembiayaan bagaimanakah track record calon nasabah. Ali Najamuddin mengatakan: "kalo DHN itu salah satu hal wajib yang harus kita periksa, jadi ya pasti kita lakukan seperti halnya dengan pengecekan SLIK OJK."(Najamuddin, 2021).

Aris juga menambahkan "Untuk pengecekan DHN biasanya dilakukan pertama saat calon nasabah mengajukan pembiayaan bu, jadi itu sudah menjadi kewajiban dan apabila akan pencairan dan itu belum dilakukan, maka harus dilakukan dahulu, dan apabila hasilnya ternyata calon nasabah masuk DHN, padahal saat dilakukan analisis sudah sesuai dan disetujui untuk diberikan pembiayaan, maka hal tersebut bisa dibatalkan, kecuali memang ada alas an dan dikuatkan dengan bukti yang ada kenapa calon nasabah tersebut bisa masuk dalam DHN."

Bank Syariah Indonesia KCP Nganjuk sendiri sudah melakukan pengecekan DHN calon nasabah sesuai dengan teori yang ada, karena ini adalah syarat adanya suatu pencairan apabila calon nasabah disetujui untuk diberikan pembiayaan.

7. Lakukan pengecekan dengan supplier

Menurut Geged "Tidak selalu itu dilakukan, karena tidak selalu mendapatkan data untuk itu, dan karena kita sudah cek dari SLIK OJK dan dari lingkungan sekitar saya rasa sudah cukup, karena kadang ada nasabah yang keberatan karena malu kalau ketauan meminjam di bank."(Geged, 2021).

Pihak Bank Syariah Indonesia KCP Nganjuk tidak selalu melakukan pengecekan dengan supplier, karena kurang sesuai dengan teori, sehingga hasil analisis menjadi kurang tajam dan masih terdapat nasabah yang bermasalah dalam pembayaran angsuran pembiayaan.

8. Memperlajari karakter masyarakat setempat

Memperlajari karakter masyarakat setempat, karena adat di setiap daerah sangat berbeda, apakah calon nasabah masuk dalam daftar masyarakat yang disegani didaerah itu? Kenapa disegani? Apakah karena mempunyai nama baik yang besar atau sebaliknya 
Etihad: Journal of Islamic Banking and Finance

Vol. 1, No. 2 Juli-Desember: 158-171

mempunyai reputasi yang buruk. Menurut Ali Najamuddin : "Jadi di setiap wilayah kan kadang ada wilayah yang biasanya warganya banyak yang macet pembiayaannya, sehingga itu kita hindari, namun tidak selalu, kalo memang ada rekom dan setelah di Analisis itu masuk ke calon nasabah yang bagus ya tetep akan kita proses, tanpa melihat wilayah asalnya."(Najamuddin, 2021).

Dari hasil analisis menggunakan hasil wawancara dengan Bank Syariah Indonesia KCP Nganjuk, didapatkan hasil bahwa dari hasil penelitian yang dilakukan di BMT Al-Fatayya (Hurriyah, 2018) yang menyatakan bahwa karakter adalah hal terpenting dalam analisis pembiayaan. Dari teori tersebut menjelaskan bahwa penilaian karakter merupakan faktor yang dominan, karena jika nasabah mampu untuk menyelesaikan utangnya, namun tidak mempunyai iktikad baik, maka akan membawa berbagai kesulitan bagi bank di kemudian hari (Andrianto \& Firmansyah, 2019). Dalam hal ini, didapati ketidaksesuaian dalam beberapa poin pada penilaian dengan menggunakan analisis karakter, karena di Bank Syariah Indonesia KCP Nganjuk menerapkan 5C secara lengkap, walaupun menurut mereka karakter adalah hal penting. Namun karakter bisa berubah seiring dengan kondisi keuangan, kondisi ekonomi seperti karena adanya covid-19, karakter nasabah yang tidak jujur, kondisi usaha, atau pekerjaan yang dimanipulasi baik stok barang dan supllier, pembelian barang tidak sesuai dengan yang diajukan, sehingga nasabah ingkar janji dan tidak memenuhi tanggung jawabnya untuk mengangsur pembiayaannya kepada pihak bank.

\section{KESIMPULAN}

Analisis pembiayaan pada calon nasabah Bank Syariah Indonesia KCP Nganjuk dengan menerapkan analisis karakter nasabah yang merupakan sesuatu yang bersifat sangat penting. Karakter itu adalah sifat dasar yang sangat sulit untuk diubah, sehingga merupakan salah satu prioritas utama dalam melakukan analisis pembiayaan. Akan tetapi Bank Syariah Indonesia KCP Nganjuk tetap melakukan analisis 5 C secara lengkap dalam menjalankan proses analisis pembiayaannya. Bank Syariah Indonesia KCP Nganjuk sudah melakukan analisis karakter walaupun semuanya poin analisis karakter belum dilaksanakan secara maksimal. Dalam hal ini, maka diperlukan analisis karakter kepada calon nasabah pembiayaan murabahah secara lebih cermat dan mendalam tanpa mengesampinkan analisis $5 \mathrm{C}$.

\section{REFERENSI}

Afri Dewita, S. P. (2019). Pendidikan Karakter Bagi Anak Usia Dini. https://pauddikmassumbar.kemdikbud.go.id/artikel/42/pendidikan-karakter-bagi-anakusia-dini

Andrianto, \& Firmansyah, M. A. (2019). Manajemen Bank Syariah. Qiara Media.

Aris. (2021). Wawancara.

Bprartorejobatu. (2021). Pengertian Kredit. http://bprartorejobatu.com/pengertiankredit/\#: :text=Sesuai Undang-Undang No. 10,setelah jangka waktu tertentu dengan

Budiantoro, S. (2014). Mengawal Green Banking Indonesia. 28. 
Etihad: Journal of Islamic Banking and Finance

Vol. 1, No. 2 Juli-Desember: 158-171

Danim, S. (2002). Riset Keperawatan: Sejarah dan Metodologi. Penerbit Buku Kedokteran EGC. Geged. (2021). Wawancara.

Hurriyah, D. (2018). Analisis Penilaian Karakter Dalam Penyaluran Pembiayaan Murabahah Pada KSPPS BMT Alfataya Payakumbuh. Jurnal IAIN Batu Sangkar, 1.

Ilyas, R. (2015). Konsep Pembiayaan Dalam Perbankan Syariah. Jurnal Penelitian, 1.

Ismail. (2016). Manajemen Perbankan: Dari Teori Menuju Aplikasi. Premadia Group.

Kasmir. (2013). Dasar-Dasar Perbankan. Rajawali Pers.

Kasmir. (2016). Bank dan Lembaga Keuangan Lainnya. Rajawali Pers.

Najamuddin, A. (2021). Wawancara.

Novita, E. (2017). Perbedaan Penerimaan Diri Ibu yang Memiliki Anak Tunagrahita ditinjau dari Tingkat Pendidikan di SLB-E PTP Medan. Jurnal Diversita, 3(1), 55. https://doi.org/10.31289/diversita.v3i1.1180

OJK. (2021a). APA PERBEDAAN BLACKLIST NASIONAL, BI CHECKING, DAN SISTEM INFORMASI DEBITUR? https://sikapiuangmu.ojk.go.id/FrontEnd/CMS/Article/323

OJK. (2021b). SISTEM LAYANAN INFORMASI KEUANGAN (SLIK). SISTEM LAYANAN INFORMASI KEUANGAN (SLIK)

Pengertian, Fungsi dan Jenis Analisis Rasio Keuangan. (2021). https://www.jurnal.id/id/blog/pengertian-fungsi-analisis-dan-jenis-rasio-keuangan/

Saiful. (2021). Wawancara.

Selvi Safitry, \& Hendry, A. (n.d.). Prosedur Analisis Kelayakan Pembiayaan Mikro: Studi Kasus BRI Syariah Cabang Prabumulih. Jurnal Ekonomi Dan Perbankan Syariah, 1, 41.

Sistem Layanan Informasi Keuangan (SLIK).

(2021). https://sikapiuangmu.ojk.go.id/FrontEnd/CMS/Article/10422

Sugiyono. (2017). Metode Penelitian Bisnis Pendekatan Kuantitatif, Kualitatif, Kombinasi dan $R \& D$. Alfabeta. 